\title{
Analysis of the roles of mutations in thyroid hormone receptor- $\beta$ by a bacterial biosensor system
}

\author{
Changhua Shi, ${ }^{1,2}$, Qing Meng' and David W Wood ${ }^{2}$ \\ ${ }^{1}$ Institute of Biological Sciences and Biotechnology, Donghua University, Shanghai 201620, People's \\ Republic of China \\ ${ }^{2}$ Department of Chemical and Biomolecular Engineering, Ohio State University, Columbus, Ohio 43210, USA
}

Correspondence should be addressed to D W Wood

Email

wood.750@osu.edu

\begin{abstract}
Mutations in thyroid hormone receptors (TRs) often lead to metabolic and developmental disorders, but patients with these mutations are difficult to treat with existing thyromimetic drugs. In this study, we analyzed six clinically observed mutations in the ligand-binding domain of the human TR $\beta$ using an engineered bacterial hormone biosensor. Six agonist compounds, including triiodothyronine $\left(T_{3}\right)$, thyroxine $\left(T_{4}\right), 3,5,3^{\prime}$-triiodothyroacetic acid (Triac), GC-1, KB-141, and CO-23, and the antagonist NH-3 were examined for their ability to bind to each of the TR $\beta$ mutants. The results indicate that some mutations lead to the loss of ability to bind to native ligands, ranging from several fold to several hundred fold, while other mutations completely abolish the ability to bind to any ligand. Notably, the effect of each ligand on each TR $\beta$ mutant in this bacterial system is highly dependent on both the mutation and the ligand; some ligands were bound well by a wide variety of mutants, while other ligands lost their affinity for all but the WT receptor. This study demonstrates the ability of our bacterial system to differentiate agonist compounds from antagonist compounds and shows that one of the TR $\beta$ mutations leads to an unexpected increase in antagonist ability relative to other mutations. These results indicate that this bacterial sensor can be used to rapidly determine ligand-binding ability and character for clinically relevant TR $\beta$ mutants.
\end{abstract}
Key Words
- thyroid hormone receptor
- ligand-binding assay
- hormone receptor mutations
- engineered biosensor

\author{
Journal of Molecular \\ Endocrinology \\ (2014) 52, 55-66
}

\section{Introduction}

Thyroid hormone receptors (TRs) belong to the nuclear hormone receptor (NHR) superfamily, which includes a wide variety of transcriptional regulators that respond to various small-molecule hormones. TRs specifically regulate those genes that respond to various levels of native thyroid hormones. Similar to other NHRs, TRs can be structurally divided into several domains: two conserved activation function domains (AF1 and AF2) and a DNA-binding domain (DBD) connected to the ligand-binding domain (LBD) through a hinge domain (Zhang \& Lazar 2000). In humans, there are two TR subtypes, $\alpha$ and $\beta$, expressed by two different genes located on chromosomes 17 and 3 respectively (Cheng 2000, Zhang \& Lazar 2000). Alternate RNA splicing gives rise to several isoforms for each subtype, some of which cannot respond to thyroid hormone ligands. Of the TR $\alpha$ isoforms, only TR $\alpha 1$ exhibits the ability to bind to the native thyroid hormone triiodothyronine $\left(T_{3}\right)$, while all the three TR $\beta$ isoforms have $\mathrm{T}_{3}$-binding ability. The expression levels of the various TRs within a given cell depend on both tissue type and developmental stage for a given animal (Cheng 2000). 
TRs play a critical role in mammalian metabolism and development through the regulation of gene transcription. A zinc-binding domain in the TR DBD binds to a double-stranded DNA at specific sequences, forming a homodimer or heterodimer with retinoid X receptor (RXR). In the absence of thyroid hormones, TR/RXR heterodimers bind to co-repressors, such as the nuclear receptor co-repressor $(\mathrm{N}-\mathrm{CoR})$, or the silencing mediator of retinoid and thyroid receptors (SMRT). These complexes contain histone deacetylases, which create a closed chromatin conformation leading to transcriptional repression (Fondell 2013, Pascual \& Aranda 2013). In the presence of thyroid hormones, the conformation of TRs changes to destabilize co-repressor binding and favor the recruitment of transcriptional co-activators, leading to gene transcription. Depending on the co-activators and co-repressors present in the cell, TRs can sometimes repress gene expression in the presence of a ligand or activate gene expression without thyroid hormones (Pascual \& Aranda 2013, Sirakov et al. 2013).

Resistance to thyroid hormone (RTH) is an inherited syndrome that reduces tissue sensitivity to thyroid hormones (Cheng 2005). RTH is characterized in vivo by an increased level of free thyroid hormone or thyroid-stimulating hormone (TSH) in the serum, while TR-dependent gene expression is not increased. Because of the importance of TRs in metabolism and development, RTH leads to many clinical symptoms, such as goiter, weight loss, hair loss, short stature, decreased IQ, and dyslexia. Increasing evidence suggests that RTH is primarily related to TR mutations, although mutations in co-activators, co-repressors, and other proteins related to thyroid metabolism (e.g., selenoproteins) can also lead to these disorders (Refetoff \& Dumitrescu 2007). The high homology of TRs across animal species has allowed RTH models to be developed using engineered mice, zebrafish, and tadpoles (Cheng 2005, Porazzi et al. 2009, Grimaldi et al. 2013). Unfortunately, these animal models do not lend themselves to high- or medium-throughput drug screening. For this reason, an inexpensive, microtiter assay for RTH therapeutics is highly desirable, especially for preclinical drug discovery and development.

In our previous work, we created several hormone biosensors through gene fusions of animal NHR LBDs to a convenient reporter protein scaffold. The resulting fusion proteins produce hormone-dependent growth phenotypes when expressed in modified Escherichia coli cells (Skretas \& Wood 2005a,b, Li et al. 2011). In particular, the binding of an appropriate ligand to the fused LBD activates a thymidylate synthase (TS) reporter enzyme, which allows the E. coli strain D1210sthyA expressing this protein to grow in media lacking thymine. This sensor is capable of differentiating agonist compounds from antagonist compounds and has shown utility in the identification and characterization of a number of compounds that bind to human and animal estrogen receptors (ERs; Gawrys et al. 2009, Gierach et al. 2013). More recently, this strategy has been validated for subtype-selective human TR ligands using a small library of known selective ligands (Gierach et al. 2012).

In this study, we introduced six clinically relevant mutations into our human TR $\beta$ biosensor (Fig. 1) and examined the resulting effects on the ability to bind to recognized native and synthetic TR ligands. These include the native agonists $T_{3}$ and thyroxine $\left(T_{4}\right)$, as well as the synthetic agonists 3,5,3'-triiodothyroacetic acid (Triac), GC-1, and KB-141, and the synthetic antagonist NH-3. Our results indicate that the effects of these TR $\beta$ mutations on ligand-binding are not equal, and that the binding of both agonists and antagonists is highly dependent on each specific mutation. Some mutations lead to partial loss of ability to bind to some ligands $\left(\mathrm{EC}_{50}\right.$ values increase several to several hundred times), while other mutants completely lost binding ability for all ligands. Surprisingly, one of the mutants has shown a significant increase in NH-3 growth inhibition relative to the WT receptor in the presence of $T_{3}$, suggesting that this mutation may disrupt $\mathrm{T}_{3}$ interactions with the binding pocket, while leaving those for NH-3 more intact.

\section{Materials and methods}

\section{Reagents}

The ligands Triac $(95 \%), \mathrm{T}_{3}$ (sodium salt hydrate, 95\%), 17-estradiol $\left(\mathrm{E}_{2}\right)$, and $\mathrm{T}_{4}$ were purchased from Sigma. The ligands GC-1 (3,5-dimethyl-4-(4'-hydroxy-3'-isopropylbenzyl) phenoxy acetic acid) and KB-141 (3,5-dichloro4-(4'-hydroxy-3'-isopropylphenoxy) phenyl acetic acid) were a gift from Dr Gary Grover (University of Medicine and Dentistry of New Jersey, Newark, NJ, USA). The ligands NH-3 (2-(4-((4-hydroxy-3-(1-methylethyl)-5-(2-(4-nitrophenyl)ethynyl)phenyl)methyl)-3,5-dimethylphenoxy) acetic acid) and CO-23 (5-((4-(4-hydroxy-3-propan2-ylphenoxy)-3, 5-diiodophenyl)methyl)imidazolidine-2, 4-dione) were a gift from Tom Scanlan (Oregon Health \& Science University, Portland, OR, USA). All other chemicals used for microbial cell culture were purchased from Fisher Scientific (Pittsburgh, PA, USA).

Published by Bioscientifica Ltd. 


\section{Construction of mutant sensors}

The mutant sensors are all based on our previously reported human TR $\beta$ sensor fusion protein. Six mutations, R243W, N331D, R338W, L346F, $\Delta 430 \mathrm{M}$, and P453H, were introduced into the human TR $\beta$ sensor LBD through overlap extension PCR using two pairs of primers annealing to the intein backbone and the mutation sites respectively (Supplementary Table S1, see section on supplementary data given at the end of this article). Overlap extension PCR products were then digested with AgeI and XhoI and ligated into pMIT:TR $\beta$ (Skretas $\&$ Wood 2005a) to replace the WT sensor and generate the mutant sensors. All the mutant constructs were confirmed by sequencing.

\section{Determination of bacterial sensor growth phenotypes}

The constructed mutant sensor plasmids were transformed into the TS (TYMS)-deficient E. coli strain D1210 $\Delta$ thyA::$\operatorname{Kan}^{\mathrm{R}}\left(\mathrm{F}^{-} \Delta\right.$ (gpt-proA) 62 leu B6 sup E44 ara-14 galK2 lacY1s (mcrC-mrr) rpsL20 (Str $\left.{ }^{\mathrm{r}}\right)$ xyl-5 mtl-1 recA13 lacl ${ }^{\mathrm{q}}$ ) and cultured on Luria-Bertani (LB) agar plates supplemented with $50 \mu \mathrm{g} / \mathrm{ml}$ thymine. The determination of phenotypes was carried out in the presence of various ligands consistently with our previously reported work (Gierach et al. 2012). The transformed cells were then cultured in $3 \mathrm{ml} \mathrm{LB}$ medium supplemented with $100 \mu \mathrm{g} / \mathrm{ml}$ ampicillin and $50 \mu \mathrm{g} / \mathrm{ml}$ thymine and incubated at $37^{\circ} \mathrm{C}$ to an $\mathrm{OD}_{600}$ value of 1.2. These seed cultures were then diluted 1:200 in liquid thymine-free medium (-THY) (per liter: $10 \mathrm{ml}$ of $10 \%$ casamino acids; $10 \mathrm{ml}$ of $20 \%$ glucose; $200 \mu \mathrm{l}$ of $1 \%$ thiamine $\mathrm{HCl} ; 200 \mathrm{ml}$ of $5 \times$ Minimal Broth, Davis (MBD: $35 \mathrm{~g}$ dipotassium phosphate, $10 \mathrm{~g}$ monopotassium phosphate, $2.5 \mathrm{~g}$ sodium citrate, $0.5 \mathrm{~g}$ magnesium sulfate, and $5 \mathrm{~g}$ ammonium sulfate, per liter); $10 \mathrm{ml}$ of Thy Pool ( $2 \mathrm{mg} / \mathrm{ml}$ of each of the following amino acids: L-Arg, L-His, L-Leu, L-Met, L-Pro, and L-Thr); and $1 \mathrm{ml}$ of $0.1 \mathrm{M}$ $\mathrm{CaCl}_{2}, \mathrm{pH}$ 7.0) supplemented with $100 \mu \mathrm{g} / \mathrm{ml}$ ampicillin. For the antagonist assay, seed cultures were diluted in thymine-free medium supplemented with $10 \mu \mathrm{M} \mathrm{T}$. For growth assays, $200 \mu \mathrm{l}$ of the diluted cells were transferred into each well of a 96-well microtiter plate, and each well was supplemented with $2 \mu \mathrm{l}$ of ligands dissolved in DMSO. Importantly, the concentration of ligand in DMSO was adjusted such that the total concentration of DMSO in each well was the same and only the concentration of ligand varied. The 96-well plates were then incubated at $34^{\circ} \mathrm{C}, 150$ r.p.m. agitation, and $80 \%$ humidity for $22 \mathrm{~h}$. Growth phenotypes were then measured by optical absorbance at a wavelength of $600 \mathrm{~nm}\left(\mathrm{OD}_{600}\right)$ using a Biotek Synergy 2 plate reader. All the assays were carried out in triplicate, and each was additionally repeated three times on three different days. The reported growth signal is the difference between the $\mathrm{OD}_{600}$ value in the presence of a ligand and that in the presence of the pure DMSO control for each mutant. The inhibition efficiency for the NH-3 antagonist is defined as the ratio of the growth signals in the presence of both NH-3 and $\mathrm{T}_{3}$ to the growth signals in the presence of $\mathrm{T}_{3}$ alone.

\section{Statistical analysis}

Growth responses in each case are based on the average of three independent experiments carried out on three different days, where each experiment was carried out in triplicate (a total of nine data points). Error bars in each figure represent a single s.D. from the mean for all the data points measured. The half-maximal effective concentration was determined by fitting the growth data to equation (1), where $X$ is the ligand concentration, $Y$ is the observed growth signal, and Bottom, Top, $\mathrm{EC}_{50}$, and Hillslope are the fitted parameters. The fitting was carried out using the software package OriginPro 8 (www.originlab.com):

$Y=$ Bottom $+\frac{\text { Top }- \text { Bottom }}{1+10^{\left(\log \mathrm{EC}_{50}-X\right) \times \text { Hillslope }}}$

The statistical significance ( $P$ value) between the signals from the wide-type and mutant receptors was determined via Student's t-test function (two-tailed, two-sample equal variance) in Microsoft Excel 2010.

\section{Results}

The LBD of TR $\beta$ contains twelve $\alpha$-helixes and four $\beta$-strands. In this study, we examined six previously reported mutations, R243W (Pohlenz et al. 1996), N331D (Rivolta et al. 2009), R338W (Weiss et al. 1993), L346F (Rivolta et al. 2009), $4430 \mathrm{M}$ (Collingwood et al. 1994), and P453H (Shuto et al. 1992), which are well distributed throughout the LBD sequence (Fig. 1 and Supplementary Figure S1, see section on supplementary data given at the end of this article). In particular, $\mathrm{R} 243 \mathrm{~W}$ is located at the end of helix 2 and therefore close to the $\mathrm{N}$ terminus of the LBD. The N331D and L346F mutations are located on a long loop between helix 6 and helix 7. The L346F mutation is located in the loop between helix 7 and helix 8, while the $\triangle 430 \mathrm{M}$ and $\mathrm{P} 453 \mathrm{H}$ mutations are located in helix 11 and helix 12 respectively (Fig. 1B and Supplementary Figure S1).

Published by Bioscientifica Ltd. 
A

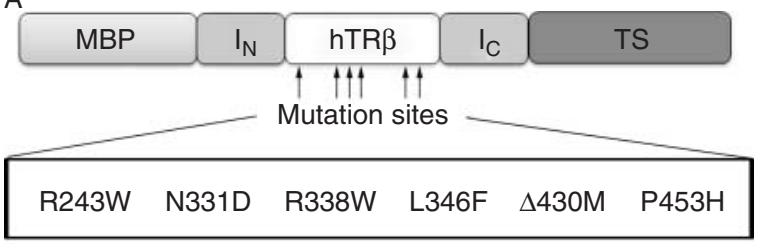

B

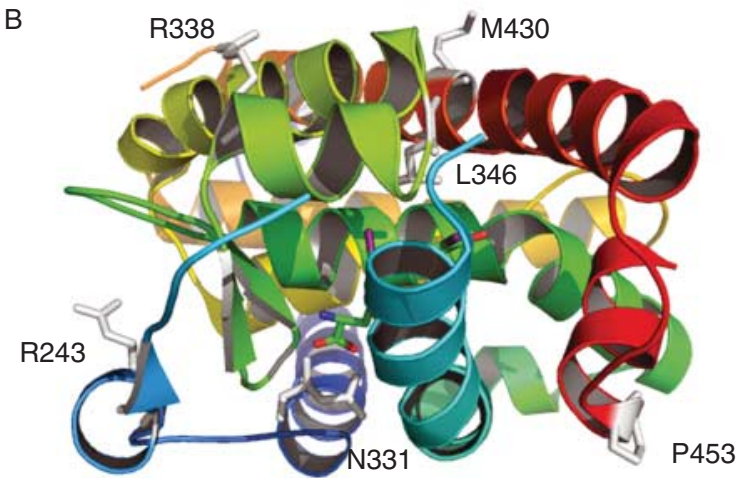

\section{Figure 1}

Human TR $\beta$ bacterial sensor protein design with tested mutations on ribbon diagram structure. (A) Schematic representation of the human TR $\beta$ bacterial sensor protein. The sensor fusion protein contains four domains: MBP is a maltose-binding protein at the $\mathrm{N}$ terminus of the sensor protein, which is believed to normalize expression and increase the solubility of the fusion protein; hTR $\beta$ is the human TR $\beta$ LBD, which is the ligand recognition element of the sensor; $\mathrm{I}_{\mathrm{N}}$ and $\mathrm{I}_{\mathrm{C}}$ are the $\mathrm{N}$ - and $\mathrm{C}$-terminal segments of $\mathrm{a}$ split intein, which is believed to stabilize the inserted TR $\beta$ LBD; and TS is a thymidylate synthase reporter protein, which generates a growth phenotype response when it is activated. The biosensor fusion is designed such that ligand-dependent conformational changes in the LBD are transferred through the intein domain to the TS domain, leading to the activation of the TS domain and generation of a readily detectable change in growth phenotype. The six mutations investigated in this study are shown below. (B) The structure of the human TR $\beta$ in complex with $T_{3}$ (protein data bank ID\#: 3GWS) indicating the mutations examined in this study. The $\mathrm{T}_{3}$ ligand is shown at the center in a colored ball-and-stick representation, where the side chains of the mutation locations (WT side chains are shown) are indicated by white ball-and-stick representations. Full colour version of this figure available via http://dx.doi.org/10.1530/ JME-13-0108.

Each mutation was introduced into the native TR $\beta$ LBD through overlap extension PCR using two pairs of primers for each mutation, and all clones were confirmed by sequencing prior to testing (Supplementary Table S1).

\section{Agonist assay}

Growth phenotypes of the mutant sensors The native TR $\beta$ sensor and the six mutant sensors were first exposed to a small library of TR agonists, which included $\mathrm{T}_{3}, \mathrm{~T}_{4}$, Triac, GC-1, KB-141, and CO-23. Of these ligands, CO-23 has been reported to bind to $\operatorname{TR} \alpha$ and $\operatorname{TR} \beta$ with a similar affinity, but it appears to preferentially activate $\mathrm{TR} \alpha$ in some assays (Kawakami et al. 2008, Grijota-Martínez et al. 2011). Phenotype tests were carried out similarly to our previous work, where the E. coli biosensor cells were grown in -THY liquid medium (see the Materials and methods section) with each ligand supplied at a final concentration of $10 \mu \mathrm{M}$ using a DMSO vehicle. Growth was quantified by measuring absorbance at $600 \mathrm{~nm}$ $\left(\mathrm{OD}_{600}\right)$, where the background is based on a pure DMSO vehicle as a control. The responses of the native and mutant sensors to the tested ligands are shown in Fig. 2. All the reported agonists, including CO-23, generated a significant growth response in the WT TR $\beta$ biosensor.

The behaviors of the TR $\beta$ mutant sensors varied, and the mutants could be divided into three groups based on the responses. The first group contained the R243W and R338W mutants, which responded to all the tested agonists. However, the signals observed for this group were generally lower than those observed for the native sensor. Notable exceptions were the Triac and GC-1 signals, which were found to be similar or higher. The second group contained the N331D and $\Delta 430 \mathrm{M}$ mutants, which did not respond to any of the agonists tested. The lack of response was characterized by no significant difference between the test ligand and vehicle-only background after $22 \mathrm{~h}$ of incubation $\left(\Delta \mathrm{OD}_{600}<0.01\right)$. The third group contained the $\mathrm{L} 346 \mathrm{~F}$ and $\mathrm{P} 453 \mathrm{H}$ mutants, which responded variably to some of the ligands. In particular,

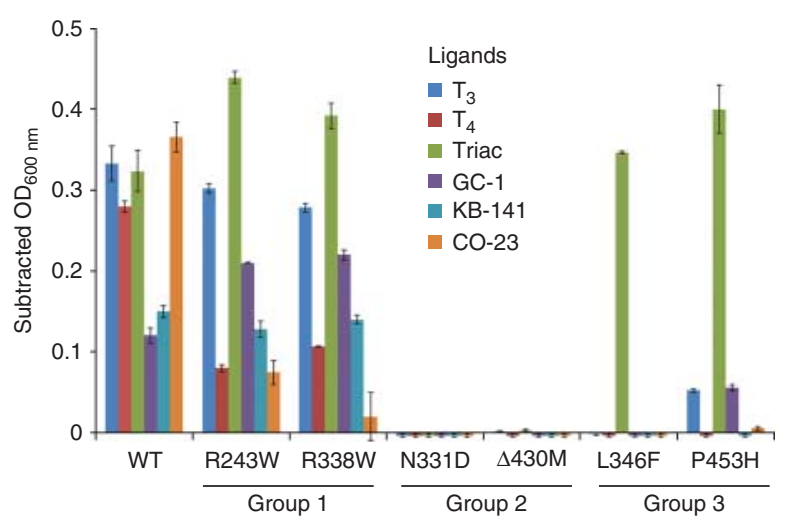

Figure 2

Growth phenotypes of the mutant and the native sensors. Mutant bacterial sensors were cultured in 96-well plates in -THY medium as described in the Materials and methods section. Each well was supplemented with the indicated TR $\beta$ agonists to a final concentration of $10 \mu \mathrm{M}$, with pure DMSO as a vehicle background control. Cell densities were read at $600 \mathrm{~nm}\left(\mathrm{OD}_{600}\right)$ after incubation at $34{ }^{\circ} \mathrm{C}$ for $22 \mathrm{~h}$. The signals shown above are the $\mathrm{OD}_{600}$ of each well above DMSO background for each mutant (subtracted OD $_{600 \mathrm{~nm}}$ ). Error bars indicate one S.D. from three replicate experiments. Full colour version of this figure available via http://dx.doi.org/10.1530/JME-13-0108.

Published by Bioscientifica Ltd. 
Table 1 Calculated $P$ values for the data shown in Fig. 2.

\begin{tabular}{|c|c|}
\hline $\begin{array}{l}P \text { values relative } \\
\text { to } W T \text { response }\end{array}$ & \\
\hline Ligand & $\begin{array}{l}\mathrm{T}_{3} \\
\mathrm{~T}_{4} \\
\text { Triac } \\
\mathrm{GC}-1 \\
\text { KB-141 } \\
\text { CO-23 }\end{array}$ \\
\hline
\end{tabular}

\begin{tabular}{|c|c|c|c|c|c|}
\hline \multicolumn{6}{|c|}{ Mutant } \\
\hline R243W & R338W & N331D & $\Delta 430 \mathrm{M}$ & L346F & $\mathrm{P} 453 \mathrm{H}$ \\
\hline 0.083 & 0.016 & NA & NA & NA & 0.00054 \\
\hline 0.00022 & 0.000013 & NA & NA & NA & NA \\
\hline 0.0024 & 0.011 & NA & NA & 0.35 & 0.0066 \\
\hline 0.000052 & 0.00011 & NA & NA & NA & 0.00075 \\
\hline 0.019 & 0.030 & NA & NA & NA & NA \\
\hline 0.00017 & 0.000172 & NA & NA & NA & NA \\
\hline
\end{tabular}

NA, no activity

the L346F mutant responded strongly to Triac alone, while the $\mathrm{P} 453 \mathrm{H}$ mutant responded to $\mathrm{T}_{3}$, Triac, and GC-1. The Triac signal was notably higher in the mutant sensors than in the native sensor for all the mutants that responded to Triac (R243W, R338W, L346F, and P453H). Each differential response was analyzed for statistical significance (Table 1), and in nearly all the cases, the differences in responses were found to be highly significant. The primary exception was the responses of the WT sensor and the L346F mutant to Triac, where the $P$ value was 0.35 . This low significance is an artifact of a similar binding affinity of both these receptors for this ligand.

Active mutant sensor responses to agonists For each ligand and mutant pair where a growth signal was observed, a dose-response curve was generated to evaluate the effect of each mutation on the apparent relative binding affinity for the ligand. The effects are reported in terms of the ligand's $\mathrm{EC}_{50}$ (half-maximal effective concentration) value for each mutant LBD (Table 2). Importantly, the dose-response curves became saturated at the highest concentration $(100 \mu \mathrm{M})$ for all the ligands in combination with the native LBD, but curves for some of the LBD mutants were unable to reach saturation at this concentration in combination with some ligands (Fig. 3). Unfortunately, solubility limitations of the test ligands in DMSO and -THY medium prevented testing at concentrations higher than $100 \mu \mathrm{M}$, which generated some uncertainty in some tests.

The effects of ligands on cell growth exhibited dependence on both the TR $\beta$ mutation and the identity of the ligands, whereby the binding ability of some ligands was affected by some mutations more than others (Fig. 3 and Table 2). For example, the $\mathrm{EC}_{50}$ values observed for the native $T_{3}$ agonist to which the first mutant group was exposed $\left(7.69 \times 10^{-6} \mathrm{M}\right.$ for the R243W mutant and $8.76 \times$ $10^{-6} \mathrm{M}$ for the R338W mutant) indicated approximately seven times weaker binding ability compared with that for the native sensor $\left(1.21 \times 10^{-6} \mathrm{M}\right)$. These changes are consistent with the previously reported values for similar mutations at the same position (R243Q) (Huber et al. 2003). In the third mutant group, decreases in binding affinity for $\mathrm{T}_{3}$ were much larger than those in the first mutant group. In particular, the $\mathrm{P} 453 \mathrm{H}$ mutant exhibited a binding affinity for $\mathrm{T}_{3}$ that was about 50 -fold lower than that exhibited by the native receptor $\left(\mathrm{EC}_{50}\right.$ value for the $\mathrm{P} 453 \mathrm{H}$ mutant was $5.80 \times 10^{-5} \mathrm{M}$ ), while the $\mathrm{L} 346 \mathrm{~F}$ mutant exhibited no $\mathrm{T}_{3}$-binding affinity. The native

Table 2 Summary of the $\mathrm{EC}_{50}$ values of different ligands for wild-type and mutant sensors.

\begin{tabular}{|c|c|c|c|c|c|c|c|c|}
\hline \multirow[b]{2}{*}{ Group } & \multirow[b]{2}{*}{ Sensors } & \multicolumn{6}{|c|}{ Agonist (M) } & \multirow{2}{*}{$\frac{\text { Antagonist (M) }}{\mathrm{NH}-3}$} \\
\hline & & $\mathrm{T}_{3}$ & $\mathrm{~T}_{4}$ & Triac & $\mathrm{GC}-1$ & KB-141 & $\mathrm{CO}-23$ & \\
\hline \multirow{3}{*}{1} & WT & $1.21 \times 10^{-6}$ & $8.31 \times 10^{-6}$ & $4.46 \times 10^{-9}$ & $1.44 \times 10^{-5}$ & $1.40 \times 10^{-5}$ & $3.42 \times 10^{-6}$ & $1.09 \times 10^{-5}$ \\
\hline & R243W & $7.69 \times 10^{-6 a}$ & $6.94 \times 10^{-2 a}$ & $8.30 \times 10^{-8}$ & $6.70 \times 10^{-6}$ & $1.03 \times 10^{-5}$ & $1.91 \times 10^{-5}$ & $3.79 \times 10^{-6}$ \\
\hline & R338W & $8.76 \times 10^{-6 a}$ & $2.94 \times 10^{-2 a}$ & $3.52 \times 10^{-8}$ & $5.81 \times 10^{-6}$ & $1.01 \times 10^{-5}$ & NA & $9.64 \times 10^{-6}$ \\
\hline \multirow[t]{2}{*}{2} & N331D & NA & NA & NA & NA & NA & NA & NA \\
\hline & $\Delta 430 \mathrm{M}$ & NA & NA & NA & NA & NA & NA & NA \\
\hline \multirow[t]{2}{*}{3} & L346F & NA & NA & $2.84 \times 10^{-6 a}$ & NA & NA & NA & NA \\
\hline & $\mathrm{P} 453 \mathrm{H}$ & $5.80 \times 10^{-5 a}$ & NA & $4.06 \times 10^{-7}$ & $4.51 \times 10^{-5 a}$ & NA & NA & NA \\
\hline
\end{tabular}

NA, no activity.

${ }^{a}$ The dose-response curve does not reach saturation.

http://jme.endocrinology-journals.org DOI: 10.1530/JME-13-0108
(C) 2014 Society for Endocrinology Printed in Great Britain
Published by Bioscientifica Ltd. 

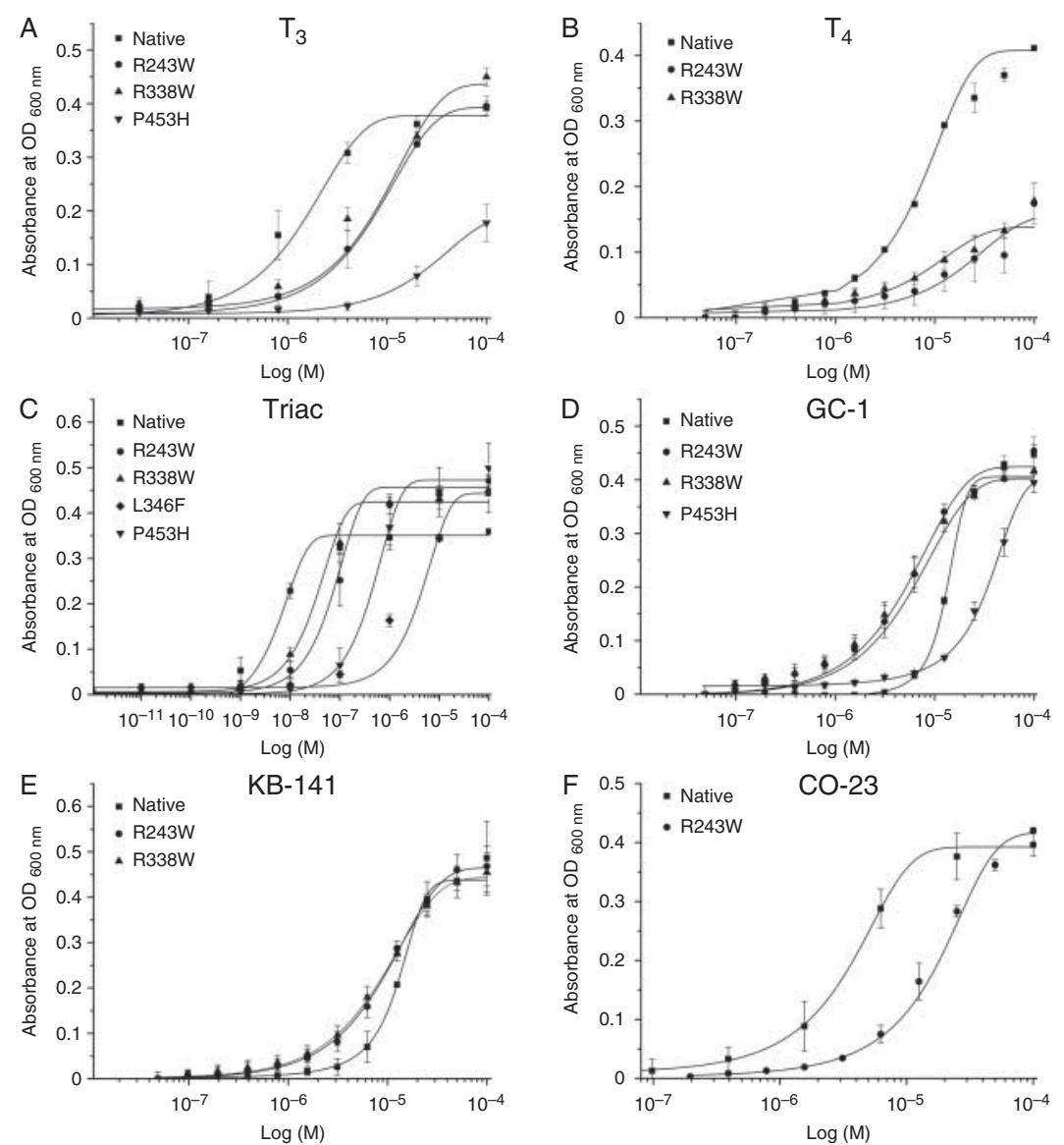

Figure 3

Dose-responses curves for the mutant and native TR $\beta$ sensors. The tested ligands are (A) $T_{3},(B) T_{4},(C)$ Triac, (D) GC-1, (E) KB-141, and (F) CO-23. Experiments were carried out at three separate time points on different days, and in triplicate each time, and fitted dose-response curves were used

$\mathrm{T}_{4}$ ligand, which is generally thought to be a storage form of $\mathrm{T}_{3}$ in vivo, was also bound by the native receptor and the first mutant group, but in all cases it showed a significantly lower binding ability than $\mathrm{T}_{3}$ (Table 2 ).

Triac, which is a strong thyroid hormone mimic, was able to bind to all the mutants in the first and third mutant groups and was the only ligand to be bound by the L346F mutant. Despite its unique binding ability, the $\mathrm{EC}_{50}$ value of Triac for the L346F mutant was over 600 times higher than that for the native receptor (Table 2), and the doseresponse curve failed to reach saturation. The Triac $\mathrm{EC}_{50}$ values for the R338W and R243W mutants are 10-fold and 20-fold higher than the native sensor, respectively, and approximately 100-fold higher for the $\mathrm{P} 453 \mathrm{H}$ mutant, indicating weaker binding for all of the mutants tested.

The responses of the native and mutant sensors to the agonist mimics GC-1 and KB-141 were different from

to calculate the $\mathrm{EC}_{50}$ values for each mutant and ligand combination. The responses shown are the mean values from three separate experiments, each of which was carried out in triplicate. Error bars represent one S.D. of each set of measurements.

those to $\mathrm{T}_{3}, \mathrm{~T}_{4}$, and Triac. Surprisingly, the observed $\mathrm{EC}_{50}$ values of GC-1 and KB-141 for the R243W and R338W mutant sensors indicated a stronger or similar binding ability compared with that for the native sensor. By contrast, $\mathrm{T}_{3}, \mathrm{~T}_{4}$, and Triac exhibited a much weaker binding ability for these mutants (Fig. 3 and Table 2). The synthetic TR $\alpha$ selective ligand, CO-23, was also tested. Although CO-23 binds with a similar affinity to both TR isoforms, it exhibits fivefold greater activation for TR $\alpha$ than for native TR $\beta$ (Ocasio \& Scanlan 2006). In our single-dose assays, CO-23 showed significant binding to only the native TR $\beta$ LBD and the R243W mutant. The $\mathrm{EC}_{50}$ value of $\mathrm{CO}-23$ was only approximately threefold higher than that of $\mathrm{T}_{3}$ for the native TR $\beta$ sensor, indicating a slightly weaker binding ability, but it exhibited a stronger binding ability than the TR $\beta$ selective agonists GC-1 and KB-141 (Table 2). The R243W mutation

Published by Bioscientifica Ltd 
decreased the CO-23-binding ability by approximately sixfold compared with that of the native receptor $\left(3.42 \times 10^{-6}\right.$ vs $\left.1.91 \times 10^{-5} \mathrm{M}\right)$.

\section{Antagonist assay}

Several compounds have been reported as known or suspected TR antagonists, including bisphenol-A (Moriyama et al. 2002, Zoeller et al. 2005), 3,5-dibromo4-(3',5'-diisopropyl-4'-hydroxyphenoxy)benzoic acid (Baxter et al. 2002), GC-14 (Nguyen et al. 2002), NH-3 (Lim et al. 2002, Nguyen et al. 2002), and a rationally designed chimera combining the TR ligand GC-1 with the alkylamide appendage of the estrogen antagonist ICI 184384 (Yoshihara et al. 2001). Of these, NH-3 is widely recognized and has been studied both in vivo and in vitro (Lim et al. 2002, Figueira et al. 2011). For these reasons, we evaluated NH-3 for its ability to antagonize the effects of $\mathrm{T}_{3}$ on the native receptor, as well as on the $\mathrm{R} 243 \mathrm{~W}$ and $\mathrm{R} 338 \mathrm{~W}$ mutant receptors. Tests were carried out in -THY medium supplemented with $10 \mu \mathrm{M} \mathrm{T}_{3}$ to allow intermediate growth of the sensor strain, while an ER $\beta$ (ESR2)-expressing strain grown in the presence of $\mathrm{E}_{2}$ was used as a toxicity and specificity control. Antagonism of $\mathrm{T}_{3}$ would be indicated by a decrease in the growth of the TR $\beta$ strain in the presence of NH-3, while the ER $\beta$ control strain would be unaffected. To account for changes in the $\mathrm{T}_{3}$-binding ability of the mutant sensors, we have defined the relative inhibition efficiency as the ratio of the $\mathrm{OD}_{600}$ value for cells grown with both $\mathrm{NH}-3$ and $\mathrm{T}_{3}$ to the $\mathrm{OD}_{600}$ value for cells grown with $\mathrm{T}_{3}$ alone.

As shown in Fig. 4A, NH-3 had a significant inhibitory effect on the TR $\beta$ strains, but no effect on the ER $\beta$ control strain. To clarify the role of NH-3 in the antagonization of $\mathrm{T}_{3}$, we incubated cells in the presence of NH-3 alone to evaluate its effects in the absence of agonist. It was observed that the growth phenotype of the cells did not change significantly from that of the background controls with any of the TR strains tested, as well as the ER $\beta$ control strain (Supplementary Figure S2, see section on supplementary data given at the end of this article). These data indicate that NH-3 is an antagonist for the native TR $\beta$ LBD, as well as for the $\mathrm{R} 243 \mathrm{~W}$ and $\mathrm{R} 338 \mathrm{~W}$ mutants, but requires the presence of the $T_{3}$ agonist to be correctly identified in this system. Surprisingly, the R243W mutant LBD strain appeared to have a greater sensitivity to $\mathrm{NH}-3$ than the native strain, based on its greater level of inhibition by $\mathrm{NH}-3$ relative to the WT sensor and the R338W mutant (Fig. 4A). Specifically, the level of inhibition for the WT sensor and the R338W mutant was $\sim 50 \%$ for equimolar $\mathrm{T}_{3}$
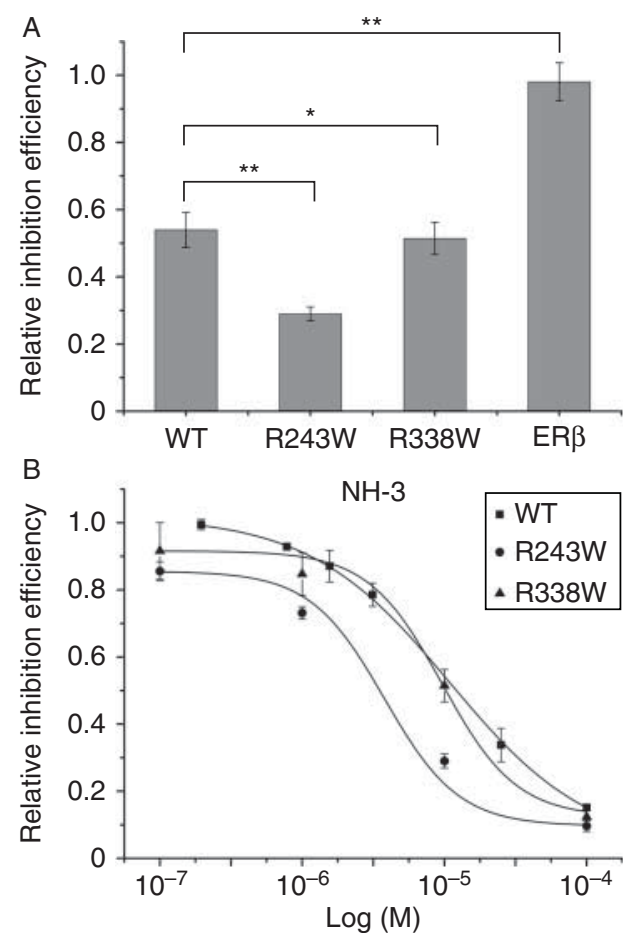

Figure 4

NH-3 antagonist assay with mutant and native sensors. (A) Growth phenotypes of the tested mutants in the presence of the $\mathrm{NH}-3$ antagonist. Sensor strains were tested in the presence of the $10 \mu \mathrm{M} \mathrm{NH}-3$ and $10 \mu \mathrm{M}$ of the respective native agonist ( $T_{3}$ for $\operatorname{TR} \beta$ and $E_{2}$ for $E R \beta$ ). (B) Dose-response curves for $\mathrm{NH}-3$ in the presence of $\mathrm{T}_{3}$ for the WT and mutant TR $\beta$ sensors. Cells were incubated in -THY medium supplemented with $10 \mu \mathrm{M} \mathrm{T}_{3}$ for $22 \mathrm{~h}$ at $34^{\circ} \mathrm{C}$, and growth was measured by absorbance at $600 \mathrm{~nm}$. Each data point is derived from three separate experiments, each of which was carried out in triplicate. Error bars indicate one s.D. from the mean. The double asterisk indicates statistically significant differences $(P<0.01)$ for each of the R243W mutant and ER $\beta$ control strains compared with the WT, and a single asterisk indicates a significant difference $(P<0.05)$ between the R338W mutant and WT.

and NH-3 (10 $\mu \mathrm{M}$ each), indicating close to equal binding affinity of each mutant for each ligand. However, the R243W mutant was inhibited to a level of $\sim 75 \%$ under these conditions, implying that this mutant exhibits a somewhat stronger preference for NH-3 than for $\mathrm{T}_{3}$.

To quantify the effect of these mutations on $\mathrm{NH}$-3-binding ability, the $\mathrm{EC}_{50}$ values for these three sensors were calculated from the dose-response curves (Fig. 4B). Unlike the agonists, the fitted $\mathrm{EC}_{50}$ curves for the mutant sensors were shifted to the left of the native sensor, indicating that the mutant sensors were more sensitive to the antagonist in this assay. The $\mathrm{EC}_{50}$ value for the $\mathrm{R} 243 \mathrm{~W}$ mutant sensor was approximately one-third of that for the WT receptor $\left(3.79 \times 10^{-6}\right.$ vs $\left.1.09 \times 10^{-5} \mathrm{M}\right)$, while the value for the R338W mutant was close to that for the native sensor $\left(9.64 \times 10^{-6}\right.$ vs $\left.1.09 \times 10^{-5} \mathrm{M}\right)$.

Published by Bioscientifica Lto. 


\section{Discussion}

In this study, we employed an engineered bacterial sensor to study the role of RTH-associated mutations in the human TR $\beta$ LBD. Using our system, we examined the impacts of six mutations distributed throughout the TR $\beta$ LBD sequence on ligand-binding ability. The results indicate that our sensor system can distinguish between mutant and WT receptors and can provide quantitative estimates of the potential effects of different LBD mutations on ligand-binding ability. In particular, our results suggest that different mutations affect ligandbinding activities differently, whereby some mutations completely abolish the binding activity for any ligand, while others have varying ligand-specific effects. Finally, we found one mutation to increase the sensitivity of the LBD to the NH-3 agonist relative to $\mathrm{T}_{3}$, despite this mutant exhibiting a generally lower agonist-binding activity.

As with many nuclear receptors, the TR $\beta$ ligandbinding pocket lies at the core of its C-terminal LBD (Wagner et al. 1995). Structural observations of the TR $\beta$ LBD bound to $T_{3}$ indicate that there are 13 residues that take part in ligand binding (Nascimento et al. 2006). Specific mutations at two of these residues, N331D and L346F, were examined in this study. Notably, N331D is the only difference between TR $\beta$ and TR $\alpha$ in the ligand-binding pocket and is thought to play an important role in ligand selectivity for these two TR subtypes (Wagner et al. 2001). The importance of these two residues in ligand recognition and binding may partially explain why these two mutations abolish the ability to bind to the native $\mathrm{T}_{3}$ agonist. Conversely, the $\Delta 430 \mathrm{M}$ mutation is far from the binding pocket, but is located in middle of the structurally critical helix 11. Deletion of this residue would significantly affect the configuration of this helix, probably resulting in instability of the whole structure (Fig. 1B). Both the R243W and R338W mutations are outside of the binding pocket and are therefore likely to have more subtle effects on binding and stability. This would be consistent with their observed ability to bind to all the tested ligands in this study, with varying effects on the observed $\mathrm{EC}_{50}$ dose-response values. Interestingly, a mutation similar to R243W (R243Q) has been studied by crystallography and B-factor analysis (Huber et al. 2003). The results indicated that the R243Q mutation has a destabilizing effect on the $\mathrm{N}$-terminal portion of the TR $\beta$ LBD, arising partially from the loss of a salt bridge and resulting in possible destabilization of the entire mutant LBD structure. Although this mutation does not abolish ligand-binding ability, it has been shown to decrease ligand-binding ability and increase co-repressor affinity. Finally, the P453H mutation resides outside the binding pocket on helix 12, which acts as a gatekeeper to the binding pocket and thus plays a critical role in the conformational changes associated with ligand binding (Rosen \& Privalsky 2009, Souza et al. 2011). Native helix 12 has only one negatively charged residue, while all the other residues are nonpolar. Thus, the $\mathrm{P} 453 \mathrm{H}$ mutation would change the electronic microenvironment and may impair the interaction between helix 12 and helix 3 in the presence of $T_{3}$. This change would be consistent with the $\sim 50$-fold decrease in the observed binding affinity of this mutant for $\mathrm{T}_{3}$. Importantly, the observed relative decreases in $\mathrm{T}_{3}$-binding ability in the mutants investigated in the present study are consistent with the previously reported results using conventional direct binding methods (Table 3). For example, the reported in vitro binding assays indicate that the $\mathrm{T}_{3}$-binding affinity is only $10 \%$ of that of the WT in the R338W mutant, which is consistent with our bacterial sensor (0.13), while the $\Delta 430 \mathrm{M}$ mutation has been reported to completely abolish $\mathrm{T}_{3}$-binding ability (Collingwood et al. 1994, Yoh et al. 1997). Furthermore, the reported decrease in $\mathrm{T}_{3}$-binding affinity arising from the $\mathrm{P} 453 \mathrm{H}$ mutation is much greater (only $4 \%$ of that of the WT) (Cheng et al. 1994), while our system indicates binding activity at $2 \%$ of that of the WT.

Triac has been shown to have a higher affinity for human TR receptors than $T_{3}$, although structural studies suggest that Triac is actually a worse fit for the TR $\beta$ ligandbinding pocket than $\mathrm{T}_{3}$ (Martínez et al. 2009). It has been proposed that the increased affinity of Triac for the TR $\beta$ LBD is due to entropic considerations, which complicates the analysis of mutation effects based on purely structural information. For example, the L346 residue does not directly interact with Triac, as it does with $\mathrm{T}_{3}$, but its neighboring residue $\mathrm{G} 344$ interacts with both $\mathrm{T}_{3}$ and Triac. This might explain why the L346F mutant recovers a positive growth phenotype in the presence of Triac, although the binding affinity is $\sim 70$ times lower than that of the native receptor. The ability of Triac to affect most of the mutants tested, and more than any other ligand in our library, supports the assertion that it is a potentially useful therapeutic for a wide range of RTH patients.

Compared with $\operatorname{TR} \alpha$, TR $\beta$ exhibits a higher affinity for GC-1 (approximately fivefold) and KB-141 (approximately tenfold). This selectivity has been attributed to the N331 residue, although structural and dynamic studies indicate that the interactions are indirect and rely heavily on the configurations and dynamics of the nearby arginine residues as well (Wagner et al. 2001, Grover et al. 2005,

Published by Bioscientifica Ltd. 
Table 3 Comparison of the previously reported data and our biosensor data for selected mutants. For each mutant, the relative binding affinity for $T_{3}$ is provided (as a percentage of that of the WT), along with the assay method and reference for the previously reported work. Although the absolute $K a$ values are very different from the $\mathrm{EC}_{50}$ values reported herein, the relative binding affinities are much closer.

\begin{tabular}{|c|c|c|}
\hline Mutant & $\mathbf{T}_{3} K a \mathrm{M}^{-1}$ & Relative binding ( $\%$ WT) \\
\hline \multirow[t]{2}{*}{$\mathrm{R} 243 \mathrm{Q}$} & NR & $0.21^{a}$ \\
\hline & $1.19 \times 10^{-10}$ & 0.84 \\
\hline \multirow[t]{3}{*}{ R243W } & $1.35 \times 10^{-10}$ & 0.74 \\
\hline & $5.26 \times 10^{-10}$ & 0.12 \\
\hline & $7.69 \times 10^{-6 b}$ & 0.15 \\
\hline \multirow[t]{4}{*}{ R338W } & $1.92 \times 10^{-10}$ & 0.34 \\
\hline & $4.76 \times 10^{-10}$ & 0.09 \\
\hline & $4.76 \times 10^{-10}$ & 0.09 \\
\hline & $8.76 \times 10^{-6 b}$ & 0.13 \\
\hline \multirow[t]{3}{*}{$\Delta 430 \mathrm{M}$} & ND & ND \\
\hline & ND & ND \\
\hline & $N^{b}$ & ND \\
\hline \multirow[t]{6}{*}{$\mathrm{P} 453 \mathrm{H}$} & $6.67 \times 10^{-10}$ & 0.06 \\
\hline & $3.66 \times 10^{-10}$ & 0.08 \\
\hline & $1.75 \times 10^{-9}$ & 0.038 \\
\hline & $1.96 \times 10^{-10}$ & 0.23 \\
\hline & $1.13 \times 10^{-8 a}$ & 0.24 \\
\hline & $5.8 \times 10^{-5 b}$ & 0.02 \\
\hline
\end{tabular}

\begin{tabular}{l} 
Method \\
\hline Helix assembly assay \\
In vitro binding assay \\
In vitro binding assay \\
In vitro binding assay \\
Bacterial sensor \\
In vitro binding assay \\
In vitro binding assay \\
In vitro binding assay \\
Bacterial sensor \\
In vitro binding assay \\
In vitro binding assay \\
Bacterial sensor \\
In vitro binding assay \\
In vitro binding assay \\
In vitro binding assay \\
In vitro binding assay \\
In vitro binding assay \\
Bacterial sensor
\end{tabular}

\begin{tabular}{l} 
Reference \\
\hline Huber et al. (2003) \\
Yagi et al. (1997) \\
Yagi et al. (1997) \\
Collingwood et al. (1998) \\
This study \\
Cheng et al. (1994) \\
Yoh et al. (1997) \\
Collingwood et al. (1994) \\
This study \\
Yoh et al. (1997) \\
Collingwood et al. (1994) \\
This study \\
Collingwood et al. (1994) \\
Nagaya et al. (1992) \\
Cheng et al. (1994) \\
Yoh et al. (1997) \\
Messier et al. (2001) \\
This study
\end{tabular}

${ }^{\text {a }}$ Data collected from only the LBD.

belative binding affinity is calculated based on the measured $\mathrm{EC}_{50}$ values in $M$.

Schriks et al. 2007, Bleicher et al. 2008). Interestingly, the binding affinities for GC-1 and KB-141 are not strongly affected by the R243W and R338W (group 1) mutations, and these mutations actually appear to increase binding affinities in some cases. The only other mutant that reacts to either of these compounds is $\mathrm{P} 453 \mathrm{H}$, which responds to GC-1, $\mathrm{T}_{3}$, and Triac, but not to KB-141. This phenomenon may indicate that KB-141 may have slightly different binding interactions in the LBD or that the location of the $\mathrm{P} 435 \mathrm{H}$ mutation creates a steric hindrance of helix 12 repositioning upon KB-141 binding. An examination of the human TR $\beta$ LBD structure in complex with different ligands indicated that the binding of $\mathrm{T}_{3}$ involves 13 interactions, while that of Triac involves 11 and GC-1 has the fewest residues (nine) involved in ligand binding (Bleicher et al. 2008, Martínez et al. 2009, Li et al. 2011). This observation may explain why the affinities of native LBD for GC-1 and KB-141 are much lower than those for $\mathrm{T}_{3}$ and Triac, but the binding affinities for GC-1 and KB-141 are less affected by the R243W and R338W mutations (Table 2).

The antagonist ligand $\mathrm{NH}-3$ used in this study appeared to show a binding ability similar to $\mathrm{T}_{3}$ for the R338W mutant (based on 50\% growth inhibition at equimolar $\mathrm{T}_{3}$ and $\mathrm{NH}-3$ concentrations), but an unexpectedly higher effect than $\mathrm{T}_{3}$ on the R243W mutant (based on $75 \%$ growth inhibition at equimolar concentrations).
Because there is no solved structure for TR $\beta$ in complex with NH-3, the source of this difference in binding cannot be examined through structural analysis. The results reported herein are consistent with indirect measurements, however, where studies have been carried out using hydrogen/deuterium exchange in TR $\beta$ in the presence of specific ligands (Lim et al. 2002). For example, Polikarpov et al. showed that helix 2 of the LBD exhibits far less deuterium exchange in the presence of $\mathrm{T}_{3}$ than it does in the presence of NH-3 ( 0 vs 33\%), while the $\beta$-sheet $4 /$ helix 7 region of the LBD becomes equally substituted with both ligands (33 vs 33\%) (Figueira et al. 2011). These observations imply that $\mathrm{NH}-3$ may be more sensitive to mutations in helix 2 than $\mathrm{T}_{3}$, while both $\mathrm{NH}-3$ and $\mathrm{T}_{3}$ may be sensitive to mutations in the $\beta$-sheet $4 /$ helix 7 region. Our observations indicate that the R243W mutation, which is located on helix 2 , leads to an observed threefold increase in NH-3-binding ability compared with the WT LBD. The R338W mutation, located adjacent to helix 7 , has a much smaller impact relative to the WT sensor. These observations also indicate that although the NH-3 antagonist is a competitive binder to $\mathrm{T}_{3}$ in the LDB binding pocket, $\mathrm{NH}-3$ is likely to interact with some residues that are different from those that interact with $\mathrm{T}_{3}$. The specific details of the competition mechanism will require more study.

Published by Bioscientifica Ltd. 
Although our bacterial system is simpler and less expensive than most conventional assays, for many ligands it exhibits a significantly lower sensitivity. This is reflected in higher $\mathrm{EC}_{50}$ values when compared with values obtained in conventional transcriptional assays and in vitro binding assays. There are several possible reasons for these disparities, including differences in ligand transport into the cells and the non-transcriptional nature of the assay (Skretas et al. 2007). For example, the bacterial assay relies on free diffusion or nonspecific transport of the ligands though the cell membrane, which will be differentially affected by the physical properties of each ligand. This may partially explain the large differences in $\mathrm{EC}_{50}$ values between $\mathrm{T}_{3}$ and Triac in the bacterial assay, where many conventional assays indicate a similar binding ability (Messier et al. 2001). In addition, the non-transcriptional nature of the bacterial system relies on stoichiometric binding of ligands to the expressed reporter proteins to produce the growth signal, while transcriptional assays produce multiple reporter gene transcripts through single binding events. This difference in mechanism may account for much of the decreased sensitivity of the bacterial system relative to transcriptional assays, but has proven advantageous for detecting low-affinity compounds (Skretas \& Wood 2005a). These types of differences are inherent when comparing conventional assays that rely on completely different sensing and reporting mechanisms and typically lead to orders of magnitude differences in quantitative binding measurements from one assay to another. These differences can be greatly decreased by normalizing binding affinities within a single assay to calculate relative binding affinities, but even these strategies typically yield significant differences between assay types. This approach was applied to the binding of $\mathrm{T}_{3}$ to the mutant receptors in the bacterial system and yielded values similar to those reported in several direct binding assays (Table 3). Thus, the bacterial system can provide consistent relative binding information for ligands and mutations, at least within the inherent variations observed in many conventional assays. Furthermore, the simplicity and low cost of the bacterial assay can provide significant advantages over many conventional transcriptional and direct binding methods.

In conclusion, we applied our bacterial hormone sensor system to study the effects of six mutations in the TR $\beta$ LDB observed in clinical RTH patients. The results indicate that our bacterial sensor system can provide some quantitative information on the relative effects of each mutation and our results are qualitatively consistent with those reported by previous investigators for these mutations. Furthermore, our sensor system can correctly identify NH-3 as a clear TR $\beta$ antagonist and indicate that it exhibits an increased ability to inhibit $\mathrm{T}_{3}$ relative to the native receptor in at least one of the mutants studied. Our results indicate that the overall binding affinities for the native $\mathrm{T}_{3}$ ligand are as follows: $\mathrm{WT}>\mathrm{R} 338 \mathrm{~W}>$ $\mathrm{R} 243 \mathrm{~W}>\mathrm{P} 453 \mathrm{H}>\mathrm{L} 346 \mathrm{~F}>\mathrm{N} 331 \mathrm{D}=\Delta 430 \mathrm{M}$, and those for the antagonist are as follows: $\mathrm{R} 243 \mathrm{~W}>\mathrm{WT}=\mathrm{R} 338 \mathrm{~W}$. These results were obtained using a very simple and inexpensive assay, suggesting that this system may be used as an effective first screen for a wide range of mutant and ligand combinations. Ideally, this system can allow rapid prototyping of new mutant assay systems, with the goal of accelerating the evaluation of relatively safe thyromimetics for possible supplementation or rescue-mode applications in the early diagnosis of RTH patients.

Supplementary data

This is linked to the online version of the paper at http://dx.doi.org/10.1530/ JME-13-0108.

Declaration of interest

The authors declare that there is no conflict of interest that could be perceived as prejudicing the impartiality of the research reported.

\section{Funding}

This research was supported by startup funds from the Ohio State University and by National Natural Science Foundation of China (no. 31070698) and a PhD. Programs Foundation of the Ministry of Education of China (no. 20120075110007) to Q M.

\section{Acknowledgements}

The authors thank Tom Scanlan (Oregon Health and Sciences University, Portland, OR) for his gift of the $\mathrm{CO}-23$ and NH-3 compounds, as well as Gary Grover (University of Medicine and Dentistry of New Jersey, Newark, NJ) for his gift of the KB-141 and GC-1 compounds.

\section{References}

Baxter JD, Goede P, Apriletti JW, West BL, Feng W, Mellstrom K, Fletterick RJ, Wagner RL, Kushner PJ, Ribeiro RC et al. 2002 Structure-based design and synthesis of a thyroid hormone receptor (TR) antagonist. Endocrinology 143 517-524. (doi:10.1210/en.143.2.517)

Bleicher L, Aparicio R, Nunes FM, Martinez L, Gomes Dias SM, Figueira AC, Santos MA, Venturelli WH, da Silva R, Donate PM et al. 2008 Structural basis of GC-1 selectivity for thyroid hormone receptor isoforms. $B M C$ Structural Biology 8 8. (doi:10.1186/1472-6807-8-8)

Cheng SY 2000 Multiple mechanisms for regulation of the transcriptional activity of thyroid hormone receptors. Reviews in Endocrine \& Metabolic Disorders 1 9-18. (doi:10.1023/A:1010052101214)

Published by Bioscientifica Ltd. 
Cheng SY 2005 Thyroid hormone receptor mutations and disease: beyond thyroid hormone resistance. Trends in Endocrinology and Metabolism 16 176-182. (doi:10.1016/j.tem.2005.03.008)

Cheng SY, Ransom SC, McPhie P, Bhat MK, Mixson AJ \& Wintraub BD 1994 Analysis of the binding of 3,3'5-triiodo-L-thyronine and its analogues to mutant human $\beta 1$ thyroid hormone receptors: a model of the hormone binding site. Biochemistry 33 4319-4326. (doi:10.1021/ bi00180a028)

Collingwood TN, Adams M, Tone Y \& Chatterjee VK 1994 Spectrum of transcriptional, dimerization, and dominant-negative properties of 20 different mutant thyroid-hormone $\beta$-receptors in thyroid-hormone resistance syndrome. Molecular Endocrinology 8 1262-1277. (doi:10.1210/me.8.9.1262)

Collingwood TN, Wagner R, Matthews CH, Clifton-Bligh RJ, Gurnell M, Rajanayagam O, Agostini M, Fletterick RJ, Beck-Peccoz P, Reinhardt W et al. 1998 A role for helix 3 of the TR beta ligand-binding domain in coactivator recruitment identified by characterization of a third cluster of mutations in resistance to thyroid hormone. Embo Journal $\mathbf{1 7}$ $4760-4770$

Figueira AC, Saidemberg DM, Souza PC, Martínez L, Scanlan TS, Baxter JD, Skaf MS, Palma MS, Webb P \& Polikarpov I 2011 Analysis of agonist and antagonist effects on thyroid hormone receptor conformation by hydrogen/deuterium exchange. Molecular Endocrinology 25 15-31. (doi:10.1210/me.2010-0202)

Fondell JD 2013 The mediator complex in thyroid hormone receptor action. Biochimica et Biophysica Acta 1830 3867-3875. (doi:10.1016/j. bbagen.2012.02.012)

Gawrys MD, Hartman I, Landweber LF \& Wood DW 2009 Use of engineered Escherichia coli cells to detect estrogenicity in everyday consumer products. Journal of Chemical Technology and Biotechnology $\mathbf{8 4}$ 1834-1840. (doi:10.1002/jctb.2254)

Gierach I, Li J, Wu W-Y, Grover GJ \& Wood DW 2012 Bacterial biosensors for screening isoform-selective ligands for human thyroid receptors $\alpha-1$ and $\beta-1$. FEBS Open Bio 2 247-253. (doi:10.1016/j.fob.2012.08.002)

Gierach I, Shapero K, Eyster TW \& Wood DW 2013 Bacterial biosensors for evaluating potential impacts of estrogenic endocrine disrupting compounds in multiple species. Environmental Toxicology 28 179-189. (doi:10.1002/tox.20708)

Grijota-Martínez C, Samarut E, Scanlan TS, Morte B \& Bernal J 2011 In vivo activity of the thyroid hormone receptor $\beta$ - and $\alpha$-selective agonists GC-24 and CO23 on rat liver, heart, and brain. Endocrinology 152 1136-1142. (doi:10.1210/en.2010-0813)

Grimaldi A, Buisine N, Miller T, Shi YB \& Sachs LM 2013 Mechanisms of thyroid hormone receptor action during development: lessons from amphibian studies. Biochimica et Biophysica Acta 1830 3882-3892. (doi:10.1016/j.bbagen.2012.04.020)

Grover GJ, Mellstrom K \& Malm J 2005 Development of the thyroid hormone receptor $\beta$-subtype agonist KB-141: a strategy for body weight reduction and lipid lowering with minimal cardiac side effects. Cardiovascular Drug Reviews 23 133-148. (doi:10.1111/j.1527-3466. 2005.tb00161.x)

Huber BR, Desclozeaux M, West BL, Cunha-Lima ST, Nguyen HT, Baxter JD, Ingraham HA \& Fletterick RJ 2003 Thyroid hormone receptor- $\beta$ mutations conferring hormone resistance and reduced corepressor release exhibit decreased stability in the N-terminal ligand-binding domain. Molecular Endocrinology 17 107-116. (doi:10.1210/me.2002-0097)

Kawakami Y, Nozaki J, Seoka M, Kumai H \& Ohta H 2008 Characterization of thyroid hormones and thyroid hormone receptors during the early development of Pacific bluefin tuna (Thunnus orientalis). General \& Comparative Endocrinology 155 597-606. (doi:10.1016/j.ygcen.2007.09.005)

Li J, Gierach I, Gillies AR, Warden CD \& Wood DW 2011 Engineering and optimization of an allosteric biosensor protein for peroxisome proliferator-activated receptor $\gamma$ ligands. Biosensors \& Bioelectronics 29 132-139. (doi:10.1016/j.bios.2011.08.006)

Lim W, Nguyen NH, Yang HY, Scanlan TS \& Furlow JD 2002 A thyroid hormone antagonist that inhibits thyroid hormone action in vivo.
Journal of Biological Chemistry 277 35664-35670. (doi:10.1074/jbc. M205608200)

Martínez L, Nascimento AS, Nunes FM, Phillips K, Aparicio R, Dias SM, Figueira AC, Lin JH, Nguyen P, Apriletti JW et al. 2009 Gaining ligand selectivity in thyroid hormone receptors via entropy. PNAS $\mathbf{1 0 6}$ 20717-20722. (doi:10.1073/pnas.0911024106)

Messier N, Laflamme L, Hamann G \& Langlois MF 2001 In vitro effect of Triac on resistance to thyroid hormone receptor mutants: potential basis for therapy. Molecular and Cellular Endocrinology 174 59-69. (doi:10.1016/S0303-7207(00)00446-9)

Moriyama K, Tagami T, Akamizu T, Usui T, Saijo M, Kanamoto N, Hataya Y, Shimatsu A, Kuzuya H \& Nakao K 2002 Thyroid hormone action is disrupted by bisphenol A as an antagonist. Journal of Clinical Endocrinology and Metabolism 87 5185-5190. (doi:10.1210/ jc.2002-020209)

Nagaya T, Madison LD \& Jameson JL 1992 Thyroid-hormone receptor mutants that cause resistance to thyroid-hormone: evidence for receptor competition for DNA-sequences in target genes. Journal of Biological Chemistry 267 13014-13019.

Nascimento AS, Dias SM, Nunes FM, Aparício R, Ambrosio AL, Bleicher L, Figueira AC, Santos MA, de Oliveira Neto M, Fischer H et al. 2006 Structural rearrangements in the thyroid hormone receptor hinge domain and their putative role in the receptor function. Journal of Molecular Biology 360 586-598. (doi:10.1016/j.jmb.2006. 05.008)

Nguyen NH, Apriletti JW, Cunha Lima ST, Webb P, Baxter JD \& Scanlan TS 2002 Rational design and synthesis of a novel thyroid hormone antagonist that blocks coactivator recruitment. Journal of Medicinal Chemistry 45 3310-3320. (doi:10.1021/jm0201013)

Ocasio CA \& Scanlan TS 2006 Design and characterization of a thyroid hormone receptor $\alpha(\mathrm{TR} \alpha)$-specific agonist. ACS Chemical Biology 1 585-593. (doi:10.1021/cb600311v)

Pascual A \& Aranda A 2013 Thyroid hormone receptors, cell growth and differentiation. Biochimica et Biophysica Acta 1830 3908-3916. (doi:10.1016/j.bbagen.2012.03.012)

Pohlenz J, Schönberger W, Wemme H, Winterpacht A, Wirth S \& Zabel B 1996 New point mutation (R243W) in the hormone binding domain of the c-erbA $\beta 1$ gene in a family with generalized resistance to thyroid hormone. Human Mutation 7 79-81. (doi:10.1002/(SICI)10981004(1996)7:1 < 79::AID-HUMU15 > 3.0.CO;2-P)

Porazzi P, Calebiro D, Benato F, Tiso N \& Persani L 2009 Thyroid gland development and function in the zebrafish model. Molecular and Cellular Endocrinology 312 14-23. (doi:10.1016/j.mce.2009.05.011)

Refetoff S \& Dumitrescu AM 2007 Syndromes of reduced sensitivity to thyroid hormone: genetic defects in hormone receptors, cell transporters and deiodination. Best Practice \& Research. Clinical Endocrinology \& Metabolism 21 277-305. (doi:10.1016/j.beem.2007.03.005)

Rivolta CM, Olcese MC, Belforte FS, Chiesa A, Gruñeiro-Papendieck L, Iorcansky S, Herzovich V, Cassorla F, Gauna A, Gonzalez-Sarmiento R et al. 2009 Genotyping of resistance to thyroid hormone in South American population. Identification of seven novel missense mutations in the human thyroid hormone receptor $\beta$ gene. Molecular and Cellular Probes 23 148-153. (doi:10.1016/j.mcp.2009.02.002)

Rosen MD \& Privalsky ML 2009 Thyroid hormone receptor mutations found in renal clear cell carcinomas alter corepressor release and reveal helix 12 as key determinant of corepressor specificity. Molecular Endocrinology 23 1183-1192. (doi:10.1210/me.2009-0126)

Schriks M, Roessig JM, Murk AJ \& Furlow JD 2007 Thyroid hormone receptor isoform selectivity of thyroid hormone disrupting compounds quantified with an in vitro reporter gene assay. Environmental Toxicology and Pharmacology 23 302-307. (doi:10.1016/ j.etap.2006.11.007)

Shuto Y, Wakabayashi I, Amuro N, Minami S \& Okazaki T 1992 A point mutation in the 3,5,3'-triiodothyronine-binding domain of thyroidhormone receptor- $\beta$ associated with a family with generalized 
resistance to thyroid-hormone. Journal of Clinical Endocrinology and Metabolism 75 213-217. (doi:10.1210/jc.75.1.213)

Sirakov M, Skah S, Nadjar J \& Plateroti M 2013 Thyroid hormone's action on progenitor/stem cell biology: new challenge for a classic hormone? Biochimica et Biophysica Acta 1830 3917-3927. (doi:10.1016/j.bbagen. 2012.07.014)

Skretas G \& Wood DW 2005a A bacterial biosensor of endocrine modulators. Journal of Molecular Biology 349 464-474. (doi:10.1016/ j.jmb.2005.04.009)

Skretas G \& Wood DW $2005 b$ Rapid detection of subtype-selective nuclear hormone receptor binding with bacterial genetic selection. Applied and Environmental Microbiology 71 8995-8997. (doi:10.1128/AEM.71.12. 8995-8997.2005)

Skretas G, Meligova AK, Villalonga-Barber C, Mitsiou DJ, Alexis MN, Micha-Screttas M, Steele BR, Screttas CG \& Wood DW 2007 Engineered chimeric enzymes as tools for drug discovery: generating reliable bacterial screens for the detection, discovery, and assessment of estrogen receptor modulators. Journal of the American Chemical Society 129 8443-8457. (doi:10.1021/ja067754j)

Souza PC, Barra GB, Velasco LF, Ribeiro IC, Simeoni LA, Togashi M, Webb P, Neves FA, Skaf MS, Martínez L et al. 2011 Helix 12 dynamics and thyroid hormone receptor activity: experimental and molecular dynamics studies of Ile280 mutants. Journal of Molecular Biology 412 882-893. (doi:10.1016/j.jmb.2011.04.014)

Wagner RL, Apriletti JW, McGrath ME, West BL, Baxter JD \& Fletterick RJ 1995 A structural role for hormone in the thyroid hormone receptor. Nature 378 690-697. (doi:10.1038/378690a0)

Wagner RL, Huber BR, Shiau AK, Kelly A, CunhaLima ST, Scanlan TS, Apriletti JW, Baxter JD, West BL \& Fletterick RJ 2001 Hormone selectivity in thyroid hormone receptors. Molecular Endocrinology 15 398-410. (doi:10.1210/me.15.3.398)

Weiss RE, Weinberg M \& Refetoff S 1993 Identical mutations in unrelated families with generalized resistance to thyroid-hormone occur in cytosine guanine-rich areas of the thyroid-hormone receptor- $\beta$ gene analysis of 15 families. Journal of Clinical Investigation 91 2408-2415. (doi:10.1172/JCI116474)

Yoh SM, Chatterjee VK \& Privalsky ML 1997 Thyroid hormone resistance syndrome manifests as an aberrant interaction between mutant T-3 receptors and transcriptional corepressors. Molecular Endocrinology $\mathbf{1 1}$ 470-480. (doi:10.1210/me.11.4.470)

Yagi H, Pohlenz J, Hayashi Y, Sakurai A \& Refetoff S 1997 Resistance to thyroid hormone caused by two mutant thyroid hormone receptor beta, R243Q and R243W, with marked impairment of function that cannot be explained by altered in vitro 3,5,3'-triiodothyroinine binding affinity. Journal of Clinical Endocrinology and Metabolism $\mathbf{8 2}$ 1608-1614

Yoshihara HA, Apriletti JW, Baxter JD \& Scanlan TS 2001 A designed antagonist of the thyroid hormone receptor. Bioorganic \& Medicinal Chemistry Letters 11 2821-2825. (doi:10.1016/S0960894X(01)00521-2)

Zhang J \& Lazar MA 2000 The mechanism of action of thyroid hormones. Annual Review of Physiology 62 439-466. (doi:10.1146/annurev.physiol. 62.1.439)

Zoeller RT, Bansal R \& Parris C 2005 Bisphenol-A, an environmental contaminant that acts as a thyroid hormone receptor antagonist in vitro, increases serum thyroxine, and alters RC3/neurogranin expression in the developing rat brain. Endocrinology 146 607-612. (doi:10.1210/en.2004-1018)

Received in final form 23 October 2013

Accepted 29 October 2013

Accepted Preprint published online 30 October 2013
(C) 2014 Society for Endocrinology Printed in Great Britain 